\title{
How to Implement Marine Environmental Liability Insurance
}

\author{
Zhaohui Chen, Kunyao Li, Tawanda Boyson Chiota \\ School of Economics and Law \\ Bohai University \\ Jinzhou, China \\ hui4179@aliyun.com; 1317731654@qq.com; chiotatawanda@gmail.com
}

\begin{abstract}
For China, the implementation of marine liability insurance is not only an obligation determined by China's international treaty obligations, but also an objective requirement for the development of shipping, marine resources and other industries. In some areas, marine environmental liability insurance has been 'enforced to implement' through legislation and has been guided and promoted by policies. Insurance companies are also great players in the marine environmental liability insurance market. In order to implement the marine environmental liability insurance better, it is necessary to further improve the legal system; establish policy insurance institutions, reasonably determine the insurance limit and develop the marine environmental liability insurance market.
\end{abstract}

Keywords-Environmental Liability Insurance; Compulsory insurance; Policy-related insurance; Liability cap; Insurance market

\section{INTRODUCTION}

Oceans are the cradle of life, the treasure houses of resources, and the important source of support for human sustainable development. The development of offshore oil transport, ocean engineering and dumping of sewage among other human activities pose a serious threat to the marine environment and ecosystem health. Many large heavy chemical industries and nuclear power projects are distributed in coastal densely populated areas and environmentally sensitive areas, thereby becoming a major risk source. On April 20, 2010, an oil rig in BP exploded and sank into the seabed resulting in an average of 12000 barrels of crude oil leaking, and the ecological environmental deterioration along the Gulf of Mexico. China, as one of the world's second and Asia's largest oil importing countries, transports $90 \%$ of the imported oil by sea; at the same time, China's offshore oil exploration and exploitation have also made considerable progress. There are thousands of oil wells in the Bohai bay, as well as there are also some accidents about oil spilling from the ships and oil wells. In June, 2011, Penglai 19-3 oil well in Bohai Bay spilled resulting in 5500 square kilometers being polluted and 50,000 tons worth of oil leakage. As a major source of post-disaster recovery financing, commercial insurance companies have been called upon to pay for catastrophe-related losses.

Environmental liability insurance (referred to as ELI) is a public liability insurance. It features the traditional liability insurance contract, insurance coverage, insurance amount, but there are significant differences in underwriting risk which tends to pay more attention to risk assessment and monitoring [1]. There are different names and approaches to this subject in different countries, such as in China it is called Green Insurance, in the United Kingdom it is divided into Environmental Impairment Liability Insurance and Own Sit Cleanup Insurance liability insurance, the United States calls it Pollution Legal Liability Insurance. Due to its wide application around the world, the concept of environmental liability insurance system has no unified definition [2].

\section{THE PRACTICE OF MARINE ENVIRONMENTAL LIABILITY INSURANCE IN CHINA}

\section{A. Compulsory enforcement through legislation}

The oceans actually form one continuous body of water which means marine environmental pollution may infringe upon many other countries. Some international treaties, established the insurance system of marine environmental liability as mandatory. China by international treaties added the contents into domestic law, in a series of laws and regulations specified in the international treaties and in accordance with the requirements of the marine environmental responsibility insurance system. On April 1980 , <International Convention on Civil Liability for Oil Pollution Damage(1969)> has entered into force for China $;<$ Marine environmental protection law $>$ in 1982, carried out in Article 28 of the marine environment in ship oil pollution insurance liability insurance: "Any vessels carrying more than 2,000 tons of oil in bulk as cargo shall hold a valid "insurance or other financial security certificate for civil liability against oil pollution damage," or a "credit certificate for civil liability against oil pollution damage," or furnish other financial credit guarantees." This represents the earliest Chinese actions on marine environmental liability insurance legal regulations. The State Council's regulation<ship pollution prevention and control of Marine Environment Management >(2009), detailed provisions:" the international shipping vessels over 2000 tons need to hold compulsory insurance, domestic ship over 2000 tons needs a "credit certificate for civil liability for oil pollution." 2016 revised version is defined as: "if the ship is sailing in the sea areas under the jurisdiction of the people's Republic of China, the ship-owner should be in accordance with the provisions of the transportation departments of the State Council, the insured ship oil pollution liability insurance coverage or obtain corresponding financial guarantee. However, except for less than 1000 ton ships to carry non-oil substances. The owner of 
the ship against ship oil pollution liability insurance coverage or the financial guarantee amount shall not be lower than the <People's Republic of China Maritime Law >, People's Republic of China concluded or acceded to the provisions of international treaties concerning oil pollution compensation limit. In the departmental regulations," the <Measures for the implementation of civil liability insurance for oil pollution damage> promulgated by the Ministry of Communications, Article 4, Article5, and Article 6, Article 8 aiming at liability insurance form made some provisions.

In addition to the national level laws, administrative regulations, and departmental regulations, local regulations in some coastal provinces also stipulate the system of environmental liability insurance as mandatory. For example, <marine environmental protection regulations of Fujian province> (2016 Amendment) Paragraph 2 of Article 30: In the harbor engaged in oil supply and residual oil, oil receiving and processing of the ship, shall be handled according to law of civil liability insurance for oil pollution damage. Paragraph 2 of Article 33: The ship carrying oil in bulk shall be handled in accordance with the law of civil liability insurance for oil pollution damage.

\section{B. Advancing through policy guidance}

Only determine the fundamental policy and policy issues of principle, programmatic characteristics, usually not specific, but just the macro to determine the objectives and direction for a certain period of time. In the current Chinese political system, the national ministries and the local people's government guidance is usually considered to belong to the category of administrative guidance. Guidance refers to the administrative subject in its jurisdiction within the jurisdiction, in order to adapt to the complex and changeable economic and social needs, according to the national law or policy; in a timely and flexible manner to take advice, guidance, consultation, demonstration, system oriented policy, the release of information about non mandatory administrative means; in the same phase of each other, the act of realizing certain administrative purpose by means of intention or assistance. <On the work of environmental pollution liability insurance> issued by PRC State Environmental Protection Administration in in 2007 belongs to this category. In addition, <The opinions of the people's government of Zhejiang province concerning the further strengthening of environmental protection work> (2012) provides for establishment of compulsory environmental pollution liability insurance system for enterprises in key industries of heavy pollution and high risk. The $2016<$ National ecological civilization pilot area (Fujian) implementation plan > put forward: the establishment of environmental pollution liability insurance system in the field of environmental risk, and by the end of 2016 the introduction of environmental pollution in Fujian Province Compulsory liability insurance system scheme. Although these policies referred to the establishment of environmental pollution liability insurance system, the force of law is different. Compulsory environmental liability insurance law is a command-line specification which set the specific rights and obligations. The policy documents have no legal specific content, they only show the direction on the specific implementation, but also depend on the specific subject and obligation.

\section{Market participation of insurance companies}

The requirements of the law and policy guidance create a certain market demand for the environmental liability insurance market. As the insurance company is also actively involved since 2013, there are 26 insurance institutions recognized as insurance institutions with civil liability for oil pollution damage insurance underwriting qualifications. Having the qualification of the insurance company launched the environmental responsibility of corresponding insurance products, and to develop the relevant provisions in the insurance contract. Such as <Additional risk clause for oil pollution liability of Marine and inland river> by People's Insurance Company of China(PICC), by Da-Di Property Insurance Company of China, and by ChangAn Property \& Liability Insurance Limited, these provisions of the terms of the insurance liability insurance usually include: (a) caused by the leakage of the ship insurance; caused by the oil pollution of the waters, the insured to take reasonable measures to eliminate or reduce pollution and expenses; (two) the relevant departments of the government compensation to prevent or mitigate the damage and the reasonable expenses of (three); the leaked ship insurance caused by the oil pollution damage on the third, by the insurer liability should be legally; (four) law enforcement agencies for oil pollution on insurance ship fine; (five) the insured for the insured all or part of insured liability or expenses paid by the insurance the prior consent of the Cost of legal proceedings.

\section{PROBLEMS AND COUNTERMEASURES OF IMPLEMENTING MARINE ENVIRONMENTAL LIABILITY INSURANCE IN CHINA}

China has a long coastline, oil spills and other marine environmental pollution accidents have occurred from time to time of which China's marine environmental liability insurance legislation and practice are still in the exploratory stage and still need to be further developed and improved.

\section{A. The legal system needs to be further improved}

Marine environmental liability insurance system in the Chinese legislation is an extremely fragmented phenomenon. The corresponding legislation has lagged behind the trend of international legislation. China currently provides the environmental liability insurance law only in the 2017 revised $<$ Marine environmental protection law > and <Maritime law >(1992). $<$ Marine environmental protection law> relates to the marine environmental liability insurance but only in the sixty-sixth provisions: "according to the state of perfect and implementation of civil liability for oil pollution damage system; the oil pollution damage compensation by ship-owners and cargo owners to share the risk principle, the establishment of ship oil pollution insurance and oil pollution damage compensation fund system. The implementation of ship oil pollution insurance and specific measures for oil pollution damage compensation fund system shall be prescribed by the State Council. " <Maritime law > have not specific provisions of the marine environmental liability insurance, only in the Article 218 of the law by other property insurance, accident may result in losses and the liability costs can be used as insurance object, this can be seen as one of the sources of law 
for marine environmental liability insurance in a broad sense. But in both laws, there is no macroscopic significance concerning marine environmental liability insurance general provisions. The absence of a national law weakens the legal basis of pollution insurance.

In the local regulations, although the "marine environmental protection regulations of Fujian province" (2016 Amendment) Regulations on marine environmental liability insurance exist, in some other coastal provinces and the local legislative power of the city there is no similar content. For instance, the "Hebei province marine environmental protection management regulations (2012)," the Guangxi Zhuang Autonomous Region marine environment protection ordinance (2013) ".

Chinese legislation has seen this principle as relatively strong but due to the lack of a supporting system, these Regulations still have no substantial effect. China's current marine environmental liability insurance system specifications to a certain extent still encompasses some vague concepts, hence, the need for the legal system of marine environmental liability insurance to be further improved.

\section{B. Developing policy insurance and establishing underwriting institutions}

Currently there are three main modes of underwriting agencies for environmental liability insurance: the first one is the specialized insurance institutions of American style, such as the 1988 establishment of environmental protection insurance company; the second one is the Italian UNPROFOR group, established in 1990 and consists of 76 insurance companies as a joint underwriting group; the third one is a British style non specialized insurance organization, named the environmental liability insurance by the property insurance company's existing voluntary insurance [3].

Since the end of 2007, China's Jiangsu, Hubei, Hunan and other provinces have actively carried out environmental pollution liability insurance pilot projects in key industries and regions. However, due to the implementation of the voluntary insurance policy, the scale of development is still limited [4]. The marine environment insurance is different from the liability insurance of environmental liability insurance in general. Due to the fact that marine ecological damage has sustained serious harm, the amount of compensation is often huge since the insurance company will have to bear great risks. In China, the overall environmental liability insurance is not mature, there are few insurance companies willing to take risks that large. For the insured, the premium burden is huge. The insurance costs at present already amount to $12 \%$ to $30 \%$ of the ship's operation costs. To hold the ship-owner liable would impose too great a burden on the ship-owner and hence regarded as unfair [5]. The excessive premium burden will be harmful to the development of shipping, ocean oil exploitation and other industries. However, a series of serious marine environmental damage events have prompted the insurance industry to have the idea of improving the premium of marine environmental liability insurance. In the aftermath of the Deep water Horizon incident, offshore energy insurance underwriters have begun to reassess their risk exposures in response to newly perceived operational risks involving blowouts, fires, explosions, lost control of wells and other non-hurricane risks. Insurance experts expect offshore energy insurance rates to increase in the short term as a result of the perception of greater potential risk exposure [6]. It is difficult for the insurer and insured to settle a dispute over the premium rate of marine environmental liability insurance through the market.

In addition, apart from the traditional environmental tort liability, marine ecological damage and damage to the overall liquidity of the ocean, is the state property and the harm to public interest. Hence, it should not be completely in accordance with the mode of operation of the business and should be defined as a policy of insurance, naming the country designated policy insurance institutions, the establishment of the state annual budget funds, clear the relevant administrative departments on marine ecological compensation and determine the duty to insure insurance rates.

\section{Establishing limitation of marine environmental liability insurance}

Although the marine environmental liability insurance can take compulsory insurance in order to prevent potential "moral hazard", the implementation of compulsory insurance at the same time shall be subject to the limitation of liability system; a reasonable set of insurance liability limit. However, marine environmental damage itself is often very large and so is the marine environment liability insurance limit. Small losses are not conducive to the sharing of loss of hence the victim may not obtain the necessary compensation. In other words, the Insurance Company underwriting institutions and other compensation ability is limited, the marine environmental liability insurance and the insurer shall limit the compensation ability to adapt. Foreign research put forward: If the USA raises the liability cap under OPA for offshore facilities to $\$ 10$ billion from $\$ 75$ million, insurance capacity will be insufficient and more energy companies will have to self-insure [7]. Therefore, it is necessary to evaluate the amount of the marine environmental damage accurately and determine the insurance quota reasonably with the insurer's compensation capacity.

\section{Developing marine environmental liability insurance market}

Chinese marine environmental liability insurance in the insurance market situation is not optimistic, there are also some problems. First of all, in the supply of marine insurance product liability insurance, insurance products in the Chinese insurance market still have a few problems; China's major insurance companies have not yet launched a comprehensive "marine environment liability insurance. The relevant insurance mainly consist of comprehensive environmental pollution liability insurance and targeted ship oil pollution liability insurance. On the two types of insurance there are exemptions and the insurance is too wide for too narrow a geographical scope. Secondly, despite the existence of environmental pollution liability insurance in the Chinese insurance market, ship oil pollution liability insurance is equal to the marine environmental liability insurance related insurance products but out of high pollution to the marine environment the risk and its solvency considerations. Chinese insurance companies currently do not have enough cause and 
aggressively develop environmental liability insurance market for the marine environment because the liability insurance rate is low and the premium is higher, therefore insurance companies involved in the marine environmental liability insurance will lower a series of problems. Finally, the awareness of foreign environmental liability insurance is weak and enterprises lack the initiative to protect marine environmental liability insurance.

Although the development of environmental liability insurance policy is necessary, it does not mean that the commercial insurance should withdraw from the field of marine environmental liability insurance. On the contrary, the former can only play a supplementary role. The insufficient market and at the same time ocean pollution liability insurance business, it should not stop at the signing of contracts but also on the fate of premiums after. Sadly, some insurers selling liability insurance to corporate directors and officers, for example, do almost nothing to monitor the behavior of the corporations that they insure, despite the apparent advantage that they could seemingly gain by doing so. Legally requiring a vast increase in the amount of insurance purchased by enterprises associated with offshore drilling, at least partially in order to enlist the risk management services of insurers [8]. Monitoring the environmental risks of enterprises by insurance companies, can play an important role in achieving unity of commercial interests and social benefits.

\section{E. Strike a balance between voluntary and mandatory environmental liability insurance}

It is quite evident that the governance system of China's marine pollution insurance still lacks knowledge and experience. The national pollution insurance policies are more general in nature and hence no systematic legal basis and detailed implementation measures. This has left loopholes for undesirable practices by many despite efforts made by the central government over these past recent years. The regulations on pollution prevention and control of hazardous waste (SCPC 2008), approved by the standing committee of the People's Congress (SCPC) of Liaoning Province in 2008, was the first local legislation on pollution insurance in China. Article 8- "supports and encourages insurance companies to develop pollution liability insurance for hazardous waste; supports and encourages companies that produce, collect, store, transport, use and dispose hazardous waste to take pollution liability insurance. This was followed by numerous pieces of legislations in various regions with the developments of two major pollution insurance systems namely voluntary and mandatory pollution insurance. In this regard, a mandatory system of marine environmental liability insurance should also be put in place across the country especially in regions exhibiting high marine pollution risk and environmentally sensitive areas and industries like shipping and hazardous waste treatment and disposal.

A proposal on the implementation of marine environmental liability insurance mandatory system would be to incorporate it with administrative measures. All companies involved in the marine business should buy marine environmental liability insurance or risk having their environmental impact assessments not getting approved for any projects and also get downgraded in terms of their level in company behavior assessments. To add, their refusal to comply with the regulations will have to be communicated to respective banks and financial institutions which will therefore limit their credit scores.

\section{CONCLUSION}

The reality is that every marine business owner and other stakeholders could be impacted by environmental exposure. It is important to properly assess risk and take steps to have a strategic plan to enable effective response should the situation ever arise. In addition, Smart business owners who take their time to consider and analyze the unique risk for environmental exposure faced by their business realize the need for environmental liability insurance, therefore will seek to obtain it. However, a perfect legal system, policy-based insurance institutions, appropriate liability cap, and a mature marine environmental liability insurance market are very important for the implementation of marine liability insurance.

\section{REFERENCES}

[1] Gang Li. Considerations of the Construction of Environmental Liability Insurance in China (In Chinese). Journal of Southwest Petroleum University (SOCIAL SCIENCE EDITION).2014, (01). Pp.68-72.

[2] Zhongmei Lv, Theory and practice of environmental damage compensation law (In Chinese). China University of Political Science and Law press, 2013.pp.125-126.

[3] Zhongmei Lv, Theory and practice of environmental damage compensation law (In Chinese). China University of Political Science and Law press, 2013.pp.133.

[4] Chengbo Jin, Yuan Zhang. Developing marine insurance to boost marine economy (In Chinese). Economic daily.2016-09-19 (11).

[5] Hui Wang. Shifts in Governance in the International Regime of Marine Oil Pollution Compensation: A Legal History Perspective. Shifts in Compensation for Environmental Damage.2007.vol.21.pp.197-240.

[6] Kyriaki Noussia. Environmental Pollution Liability and Insurance Law Ramifications in Light of the Deepwater Horizon Oil Spill. The Hamburg Lectures on Maritime Affairs 2009 \& 2010.2012.vol.23. pp. 137-176.

[7] Kyriaki Noussia. Environmental Pollution Liability and Insurance Law Ramifications in Light of the Deepwater Horizon Oil Spill. The Hamburg Lectures on Maritime Affairs 2009 \& 2010.2012.vol.23. pp. 137-176.

[8] Kenneth S. Abraham. Catastrophic Oil Spills and the Problem of Insurance. Vanderbilt Law Review.2011.Vol.64.pp.1769-1794. 